\title{
THE LOCAL INTERFERON-CORRECTIVE THERAPY IN CHILDREN WITH CONGENITAL CLEFT LIP AND PALATE, SUFFERING FROM THE RECURRENT RESPIRATORY INFECTIONS
}

\author{
I.V. Nesterovaa, ${ }^{a, b}$ M.N. Mitropanova ${ }^{a}$, G.A. Chudilova ${ }^{a}$, S.V. Kovaleva ${ }^{a}$, E.O. Khalturina ${ }^{c}$ \\ ${ }^{a}$ RUDN University of Ministry of Education and Science of Russia, Moscow, Russian Federation \\ ${ }^{b}$ Kuban State Medical University of Ministry of Health Development of Russia, Krasnodar, Russian Federation \\ ' I.M. Sechenov First Moscow State Medical University (Sechenov University), Moscow, Russian Federation
}

\begin{abstract}
It is known that children with congenital cleft lip and palate are suffering from recurrent respiratory infections, which worsen the state of their health, and also complicate the results of reconstructive surgical treatment. The aim of the study was to detect defects of mucosal immunity in children with congenital cleft lip and palate, suffering from recurrent respiratory infections, and to create the program of local interferon corrective therapy with an assessment of its effectiveness. The studies included 56 children from the age of 1 to 3 years. Three groups of children were formed: group $1-$ 26 children with congenital cleft lip and palate (antibiotic therapy); group $2-30$ children with congenital cleft lip and palate (antibiotic therapy + local interferon therapy), group $3-$ the control group. The clinical examination included a medical history, an assessment of the symptoms of recurrent episodes of acute respiratory infections and exacerbations of chronic infections. Microbiological studies were performed using standard methods. The status of local immunity was detected: the concentrations of secretory IgA, cytokines IL-17, IL-4, IL-6, IL-1 $\beta$, IFN $\gamma$ in the oral fluid were tested by ELISA. Results of the study established that in group 1 and group 2 clinical criteria of immunodeficiency with an infectious syndrome were revealed: repeated acute respiratory viral infections from 10 or more times a year, complicated by frequent exacerbations of chronic bacterial infection (up to 10 or more per year). Assessment of the state of local immunity in children with congenital cleft lip and palate revealed a lack of sIgA compared with the control group. Before treatment in group 2 oral fluid level of IL-17, IL-6 were statistically significant increase $(p<0.05)$; the results of the study also established increase in the level of IL-1 $\beta$ and a decrease in anti-inflammatory IL- 4 and regulatory IFN $\gamma$ relative to the control group ( $\mathrm{p}>0.05)$. After complex treatment with the inclusion of local interferon therapy in group 2 the appearance of sIgA, increase in the concentration of IL-4, IL-1 $\beta$ and a decrease IL-17 in oral fluid were observed ( $p>0.05)$. The concentrations of IL-6, IFN $\gamma$ did not change $(p>0.05)$. After treatment in group 2 there were a decrease in exacerbations of chronic upper respiratory tract infection and in frequency of acute respiratory viral infections compared with group $1(\mathrm{p}<0.05)$. Positive clinical efficacy of local interferon therapy (the gel of recombinant IFN $\alpha 2 b$ in combination with oxidants - Viferon gel) in the process of staged rehabilitation of children with congenital cleft lip and palate has a protective clinical effect in reducing the frequency of acute respiratory viral infections, reducing the number of postoperative complications, reducing hospital stay, duration of antibacterial therapy and the number of exacerbations of chronic bacterial infection.
\end{abstract}

Key words: congenital cleft lip and palate, recurrent respiratory infections, immunocompromised children, complex immunorehabilitation, immunotropic therapy, mucosal immunity.

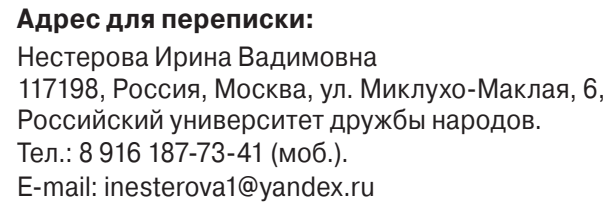

\section{Библиографическое описание:}

Нестерова И.В., Митропанова М.Н., Чудилова Г.А., Ковалева С.В., Халтурина Е.О. Локальная интерферонокорректирующая терапия у детей с врожденными расщелинами губы и неба с возвратными респираторными инфекциями // Инфекция и иммунитет. 2020. Т. 10, № 2. C. 368-374. doi: 10.15789/2220-7619-TLI-1352

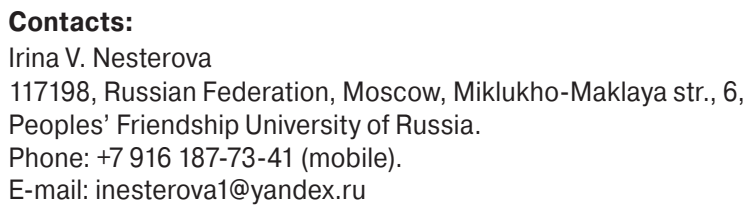

\section{Citation:}

Nesterova I.V., Mitropanova M.N., Chudilova G.A., Kovaleva S.V., Khalturina E.O. The local interferon-corrective therapy in children with congenital cleft lip and palate, suffering from the recurrent respiratory infections // Russian Journal of Infection and Immunity = Infektsiya i immunitet, 2020, vol. 10, no. 2, pp. 368-374. doi: 10.15789/2220-7619TLI-1352

DOI: http://dx.doi.org/10.15789/2220-7619-TLI-1352 


\title{
ЛОКАЛЬНАЯ ИНТЕРФЕРОНОКОРРЕКТИРУЮЩАЯ ТЕРАПИЯ У ДЕТЕЙ С ВРОЖДЕННЫМИ РАСЩЕЛИНАМИ ГУБЫ И НЕБА С ВОЗВРАТНЫМИ РЕСПИРАТОРНЫМИ ИНФЕКЦИЯМИ
}

\author{
Нестерова И.В. ${ }^{1,2}$, Митропанова М.Н. ${ }^{1}$, Чудилова Г.А. ${ }^{1}$, Ковалева С.В. ${ }^{1}$, Халтурина Е.О. ${ }^{3}$ \\ ${ }^{1}$ ФГАБОУ ВО Российский университет дружбы народов Министерства образования и науки России, Москва, Россия \\ ${ }^{2}$ ФГБОУ ВО Кубанский государственный медицинский университет Минздрава России, г. Краснодар, Россия \\ ${ }^{3}$ Первый Московский государственный медицинский университет им. И.М. Сеченова (Сеченовский университет), \\ Москва, Россия
}

Резюме. Известно, что дети с врожденной расщелиной губы и неба страдают от рецидивирующих респираторных инфекций, которые ухудшают состояние их здоровья, а также осложняют результаты реконструктивного хирургического лечения. Целью данного исследования явилось выявление дефектов мукозального иммунитета у детей с врожденной расщелиной губы и неба, страдающих рецидивирующими инфекциями респираторного тракта, а также создание программы локальной интерферонотерапии с последующей оценкой ее эффективности. В исследовании приняли участие 56 детей в возрасте от 1 года до 3 лет. Были сформированы три группы: 1-я группа - 26 детей с врожденной расщелиной губы и неба (антибиотикотерапия); 2-я группа - 30 детей с врожденной расщелиной губы и неба (антибиотикотерапия + локальная интерферонотерапия), 3-я группа - контрольная группа. Клиническое обследование включало в себя сбор анамнеза, оценку симптомов ОРВИ и обострений хронических инфекций. Микробиологические исследования проводились с использованием стандартных методов. Определяли параметры мукозального иммунитета, а именно: концентрацию sIgA, цитокинов IL-17, IL-4, IL-6, IL-1 $\beta$, IFN $\gamma$ в ротовой жидкости методом ИФА. Результаты исследования показали, что в 1-й и 2-й группах детей были детектированы клинические критерии иммунодефицита с инфекционным синдромом: повторные ОРВИ от 10 и более раз в год, осложненные частыми обострениями хронических бактериальных инфекций (до 10 и более в год). Определение параметров мукозального иммунитета у детей с врожденной расщелиной губы и неба показало отсутствие sIgA по сравнению с контрольной группой. Перед лечением у детей 2-й группы уровень IL-17, IL-6 в ротовой жидкости был статистически значимо повышен (P < 0,05); по результатам исследования также установлено повышение уровня IL-1 $\beta$ и снижение противовоспалительного IL-4 и регуляторного IFN $\gamma$ относительно группы контроля (P > 0,05). После проведения комплексной терапии с включением локальной интерферонотерапии во 2-й группе отмечается появление sIgA, повышение концентрации IL-4, IL-1 $\beta$ и снижение IL-17 в ротовой жидкости (P > 0,05). Концентрации IL-6, IFN $\gamma$ не изменились $(\mathrm{P}>0,05)$. После терапии во 2-й группе наблюдалось снижение частоты обострений хронических инфекции верхних дыхательных путей и частоты ОРВИ по сравнению с 1-й группой (P < 0,05). Позитивный клинический эффект локальной интерферонотерапии (гель рекомбинантного IFN $\alpha 2 \mathrm{~b}$ в сочетании с антиоксидантами - Виферон гель) в процессе поэтапной реабилитации детей с врожденной расщелиной губы и неба оказывает протективный клинический эффект, выражающийся в снижении частоты ОРВИ, уменьшении количества послеоперационных осложнений, сокращении времени пребывания в стационаре, снижении длительности применения антибактериальных препаратов, уменьшении количества обострений хронических очагов бактериальной инфекции.

Ключевые слова: врожденная расщелина губы и неба, рецидивирующие респираторные инфекции, иммунокомпрометированные дети, комплексная иммунореабилитация, иммунотропная терапия, мукозальный иммунитет.

\section{Introduction}

There has been a progressive increase in the number of children with congenital malformations throughout the world recently. According to WHO data, congenital clefts of the lips and palate (CCLP) are found in $0.6-1.6$ cases per 1000 newborns and in frequency of occurrence they occupy the $2^{\text {nd }}-3^{\text {rd }}$ place among all congenital malformations of a person. Every year in the Russian Federation more than 20.000 children with CCLP are born [1]. These malformations in children are not only a medical, but also a social problem and require the use of a range of rehabilitation measures, including the timely therapeutic and reconstructive surgical care. To date, the most important method of treatment for CCLP is surgical, however, the timing of surgical intervention often has to be postponed due to the high incidence of infec- tious and inflammatory diseases of the oral cavity, respiratory tract and ENT organs. A previous clinical observation in children with CCLP showed that these children suffered of complicated and uncomplicated ARVI 10 or more episodes per year with an acute period of 4 to 14 days or more, i.e. the patients were immunocompromised $[5,6]$. In addition, despite the continuous improvement of the operations technique, as well as a significant advance in patient care after plastic surgery, the frequency of early and long-term postoperative complications remains quite significant. An indisputable fact is that the formation of the inflammatory process in children with CCLP is associated with anatomical and topographic features that facilitate the penetration of pathogenic microflora onto the oral and nasal mucosa. The prolonged presence of pathogenic microflora on the mucous membranes is accompanied by impaired mu- 
cosal immunity $[2,4,10]$. In recent years, a lot of information has accumulated about the role of pro- and anti-inflammatory cytokines in providing anti-infection resistance and in the processes of the formation of inflammatory responses. Many of these cytokines are present in saliva: IL-1, IL-2, IL-4, IL-5, IL-6, IL-8, IL-17, TNF $\alpha$, IFN $\alpha$, IFN $\gamma$, epidermal growth factor and other growth factors and cytokines $[3,9,11]$. These numerous factors produce mucosal epithelium, lymphocytes and macrophages embedded in the epithelium under the influence of phologogenic stimuli entering the oral cavity and upper respiratory tract. In addition, serum transudate and salivary glands are a source of cytokines in saliva [3, 9]. An important role in anti-infection protection belongs to secretory immunoglobulin A (sIgA). Defects in mucosal immunity lead to easier invasion of pathogens and contribute to their persistence, which supports inflammatory processes. The emerging defects in the functioning of local and systemic immunity in children with CCLP require the development of new approaches to comprehensive rehabilitation. At the same time, one of the most important priority areas is the development of new immunotherapeutic approaches aimed at restoring the defective functioning of both mucosal and systemic immunity, which should, from our point of view, increase the effectiveness of comprehensive rehabilitation.

The aim of the study: to identify the features of the defects in mucosal immunity in children with CCLP, followed by an assessment of the effectiveness of local interferon therapy, which is included in the comprehensive of rehabilitation measures.

\section{Material and methods}

Treatment groups. The studies included 56 children with congenital clefts of the lips and palate (CCLP) from the age of 1 to 3 years, who are prepared for a surgical operation to repair a soft palate defect (veloplasty), or were early gentle operated to repair a hard palate defect (uranoplasty), all patients were performed cheiloplasty (surgical lip restoration) in the maxillofacial department of Facial Surgery Children's Regional Clinical Hospital in Krasnodar, Russia. The parents (guardians) of the children gave their informed consent to participate in the study in accordance with the WMA Declaration of Helsinki - Ethical Principles for Medical Research Involving Human Subjects, 2013. All procedures used in this study were approved by the Independent Ethic Committee of Kuban State Medical University (Approval No: 59 from 18.01.2018).

Three groups of children were formed randomly: group $1-26$ children with CCLP (10 boys and 16 girls), having clinical signs of secondary immunodeficiency with an infectious syndrome, under our clinical supervision (comparison group); group $2-$ 30 children with CCLP (13 boys and 17 girls) who also have clinical signs of secondary immunodeficiency with an infectious syndrome, but their comprehensive rehabilitation program included local interferon therapy by application of gel - recombinant IFN $\alpha 2 b$ in combination with antioxidants ( $\alpha$-tocopherol acetate) - Viferon (Feron, Russia). Group 3 - the control group consisted of 30 healthy children of the same age.

Samples of oral fluid were obtained during a routine examination by a dentist and were stored at $-20^{\circ} \mathrm{C}$ until further analysis.

Microbiological studies. Microbiological studies of the oral cavity, nasopharynx and nasal cavity in children with CCLP were performed to identify pathogenic and conditionally pathogenic microorganisms using standard methods.

ELISA. The state of mucosal immunity was studied in all groups of children. In group 2, studies of mucosal immunity were performed twice before and after local interferon therapy. To assess the state of mucosal immunity in the oral fluid samples, the concentrations of secretory $\operatorname{IgA}(\operatorname{sgA})$ and cytokines IL-17, IL-4, IL-6, IL-1 $\beta$, IFN $\gamma$ were determined by enzyme-linked immunosorbent assay (ELISA) by microplate reader (Ascent, Finland) using appropriate test systems ("Vector-Best", Russia) following the manufacture's instruction.

Statistical analysis. A statistical processing of the results was carried out using computer programs Microsoft Excel, StatPlus 2009 using nonparametric tests of Wilcoxon and Mann-Whitney and parametric Student's test. The results were presented as the median with the upper and lower quartiles (Me [Q1; Q3]) or as arithmetic mean and the error of the mean $(\mathrm{M} \pm \mathrm{m})$ depending on distribution. The significance of the differences was determined at $p<0.05$.

\section{Results}

Analysis of the clinical status of children with CCLP in groups 1 and 2 revealed the clinical criteria for secondary immunodeficiency with an infectious syndrome: repeated ARVI from 12 or more times a year, complicated by frequent exacerbations (up to 10 or more per year) of chronic bacterial infection in the form of chronic rhinitis, chronic tonsillitis, chronic sinusitis, chronic pharyngotracheitis. Children received from 8 or more courses of antibacterial therapy per year, including the latest generation of cephalosporins used parenterally (tabl. 1).

According to the results of microbiological and bacteriological studies, 10 cultures of gram-positive (S. epidermidis, S. viridans, S. pneumoniae, E. durans, E. faecium, E. faecalis) and gram-negative (Haemophilus influenza, Haemophilus parainfluenzae) bacterial microorganisms, as well as $C$. albicans and C. krusei, were identified. We also have established that the composition and density of microbial communities in different biotopes in children with con- 
genital cleft lip and palate is not the same. In all studied biotopes from all groups we revealed significant changes in the qualitative and quantitative composition of microbes.

In the course of the study, it was revealed that patients with group 1 and group 2 with CCLP had disturbances in the microbiocenosis of the oral cavity and upper respiratory tract against the background of physiological inflammation of the gum mucosa during eruption of temporary teeth. The most common bacterial associations were $S$. viridans, $S$. pneumoniae, Enterococcus faecalis (in $30 \%$ of cases), and monocultures of bacteria mainly E. durans, E. faecium, S. epidermidis, Haemophilus influenza (in $70 \%$ of cases) and Candida albicans (in $20 \%$ of cases) with an abundance of soft plaque. Viral infections were represented by persistent respiratory and herpetic viruses, repeated acute herpetic stomatitis. Thus, a decrease in anti-infectious resistance was associated with persistent viral and bacterial infection.

Assessment of the state of local immunity in children with CCLP revealed a lack of SIgA in the OF compared with the control group of the corresponding age (fig. 1).

A statistically significant increase in CCLP level of IL-17 in 4.03 times to $21.8[10.0 ; 37.8] \mathrm{pg} / \mathrm{ml}$ vs. $5.4[3.8 ; 5.9]$ in the control ( $\mathrm{p}<0.05)$, IL-6 up to 3.8 $[1.37 ; 4.3] \mathrm{pg} / \mathrm{ml}$ vs. $2.63[2.41 ; 2.85] \mathrm{pg} / \mathrm{ml}(\mathrm{p}<0.05)$.
The results of a study of IL-1 $\beta$ level in CCLP allowed to establish only a tendency to increase - 42.13 [30.0; 57.8$] \mathrm{pg} / \mathrm{ml}$ vs $34.3[27.3 ; 36.1] \mathrm{pg} / \mathrm{ml}$ in control $(\mathrm{p}>0.05)$ and decrease in anti-inflammatory IL-4 $(p>0.05)$ and regulatory $\operatorname{IFN} \gamma(p>0.05)$ relative to control values of relatively healthy children (fig. 2 , tabl. 2).

Taking into account the identified defects in the functioning of antiviral immunity, the presence of clinical criteria for secondary immunodeficiency with an infectious syndrome, and the clinical status of patients at different stages of surgical treatment of congenital cleft lip and palate, we developed a program of local interferon therapy to prevent the occurrence of acute respiratory viral infections and reduce the incidence of bacterial infections of the nose and oropharynx, as well as the incidence of postoperative complications.

In both clinical groups antibacterial therapy was prescribed empirically, according to current information about the resistance of pathogens to certain antibacterial drugs. Further, the correction of antibiotic therapy was carried out in view of the results of bacteriological studies (inoculation of the microflora of the oral cavity, nasal cavity and nasopharynx) and determination of sensitivity to antibiotics. The drugs of choice were antibacterial agents from the group of cephalosporins (lifaxone, cefaxone,

Table 1. Comparative clinical efficacy of complex local interferon therapy in children with congenital clefts of the lip and palate and secondary immunodeficiency $(M \pm m)$

\begin{tabular}{|l|c|c|c|c|}
\hline \multicolumn{1}{|c|}{$\begin{array}{c}\text { Clinical criteria of treatment } \\
\text { efficacy }\end{array}$} & $\begin{array}{c}\text { Before } \\
\text { therapy }\end{array}$ & $\begin{array}{c}\text { Group 1 } \\
\text { Antibiotic therapy }\end{array}$ & $\begin{array}{c}\text { After therapy } \\
\text { Local interferon therapy+ } \\
\text { antibiotic therapy }\end{array}$ & Significance \\
\cline { 3 - 5 } Number of ARVI cases per year & $12.3 \pm 1.2$ & $8.6 \pm 1.8$ & $4.9 \pm 2.3$ & $\begin{array}{c}\mathrm{p}_{1.2}<0.05 \\
\mathrm{p}_{1.3}<0.05 \\
\mathrm{p}_{2.3}<0.05\end{array}$ \\
\hline $\begin{array}{l}\text { Number of ARVI exacerbation cases } \\
\text { per year }\end{array}$ & $10.3 \pm 0.58$ & $8.03 \pm 0.74$ & $\mathrm{p}_{1.2}<0.05$ \\
\hline $\begin{array}{l}\text { Number of chronic bacterial infection } \\
\text { exacerbation cases per year (chronic } \\
\text { rhinitis, chronic tonsillitis, chronic } \\
\text { sinusitis, chronic pharyngotracheitis) }\end{array}$ & $5.1 \pm 2.61$ & $4.5 \pm 0.52$ & $3.4 \pm 0.34$ & $\mathrm{p}_{1.3}<0.05$ \\
\hline $\begin{array}{l}\text { Number of antibiotic therapy courses } \\
\text { per year (including parenteral) }\end{array}$ & $8.96 \pm 0.12$ & $7.20 \pm 0.86$ & $3.8 \pm 0.56$ & $\mathrm{p}_{2.3}<0.05$ \\
\hline
\end{tabular}

Table 2. The state of mucosal immunity in children with congenital cleft lip and palate before and after local interferon therapy (Me [Q1; Q3])

\begin{tabular}{|c|c|c|c|c|c|c|}
\hline Group & IL-17, pg/ml & IL-4, pg/ml & IL-6, pg/ml & $\mathrm{IL}-1 \beta, \mathrm{pg} / \mathrm{ml}$ & IFN $\gamma, \mathrm{pg} / \mathrm{ml}$ & slgA, g/I \\
\hline Control & $\begin{array}{c}5.4 \\
{[3.8 ; 5.9]}\end{array}$ & $\begin{array}{c}18.65 \\
{[15.1 ; 19.14]}\end{array}$ & $\begin{array}{c}2.63 \\
{[2.4 ; 2.85]}\end{array}$ & $\begin{array}{c}34.31 \\
{[27.3 ; 36.13]}\end{array}$ & $\begin{array}{c}16.74 \\
{[5.2 ; 17.3]}\end{array}$ & $\begin{array}{c}0.51 \\
{[0.46 ; 0.63]}\end{array}$ \\
\hline $\begin{array}{l}\text { Group } 2 \\
\text { before } \\
\text { treatment }\end{array}$ & $\begin{array}{c}21.28^{*} \\
{[0.01 ; 37.8]}\end{array}$ & $\begin{array}{c}12.4^{\star} \\
{[7.1 ; 13.1]}\end{array}$ & $\begin{array}{c}3.8^{\star} \\
{[1.4 ; 4.32]}\end{array}$ & $\begin{array}{c}42.13 \\
{[30.0 ; 57.8]}\end{array}$ & $\begin{array}{c}12.7 \\
{[8.11 ; 17.5]}\end{array}$ & $0^{*}$ \\
\hline $\begin{array}{l}\text { Group } 2 \text { after } \\
\text { treatment }\end{array}$ & $\begin{array}{c}14.18^{\star} \# \\
{[5.3 ; 33.6]}\end{array}$ & $\begin{array}{c}17.3 \\
{[15.9 ; 18.9]}\end{array}$ & $\begin{array}{c}2.14 \\
{[1.37 ; 5.3]} \\
\end{array}$ & $\begin{array}{c}57.3^{*} \# \\
{[45.9 ; 63.96]}\end{array}$ & $\begin{array}{c}11.8 \\
{[9.6 ; 16.9]}\end{array}$ & $\begin{array}{c}0.32^{\star} \\
{[0.29 ; 0.30]}\end{array}$ \\
\hline
\end{tabular}




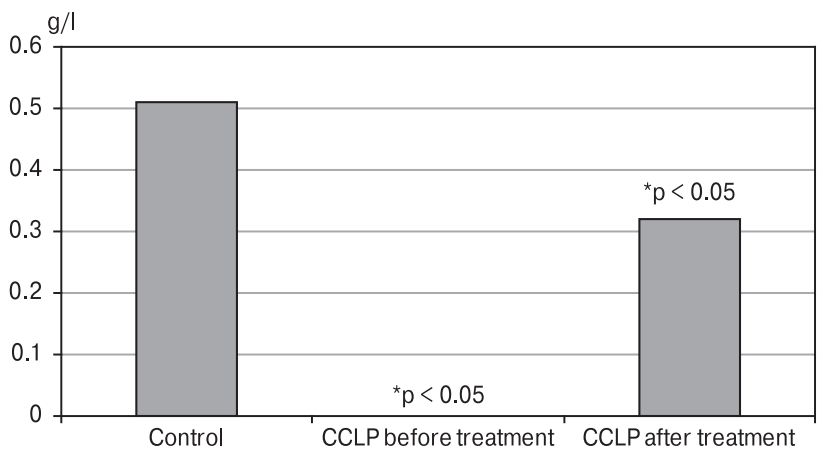

Figure 1. Concentration of secretory immunoglobulin A in children with congenital cleft lip and palate before and after local interferon therapy

Note: *significance of control group.

cephalosporin, azaran, ceftriaxone, etc.). The dose of the drug and the duration of course was determined by the age of the child, its weight, concomitant somatic pathology and the nature of postoperative complications.

In children of group 2, a locally recombinant interferon $\alpha 2 b$ gel was used by application of the mucous membrane of oral cavity and nose 3-4 times a day 10 days before surgical treatment and within 1 month after surgical treatment starting on the second postoperative day.

The total duration of the course of local interferon therapy before and after surgical treatment was 10 days and 1 month accordingly.

After the complex treatment through the local interferon therapy with recombinant interferon alfa$2 \mathrm{~b}-$ gel in children of group 2 with CCLP, there was noted the appearance of SIgA $0.32[0.29 ; 0.30] \mathrm{g} / 1$ in the OF $(\mathrm{p}<0.05)$, reaching a lower control value of $0.45[0.34 ; 0.60] \mathrm{g} / 1$, increase of the concentration of IL-4 to 17.3 [15.9; 18.96$] \mathrm{pg} / \mathrm{ml}$ to a control level $(\mathrm{p}>0.05)$, as well as a level of IL-1 $\beta$ to 57.3 [45.9; $63.96] \mathrm{pg} / \mathrm{ml}(\mathrm{p}<0.05)$ against the decrease in the amount of IL-17 to $14.18[5.3 ; 33.6] \mathrm{pg} / \mathrm{ml}(\mathrm{p}<0.05)$ and unchanging values of the concentration of IL-6, IFN $\gamma(\mathrm{p}>0.05)$.

The developed tactics of local interferon therapy demonstrated a pronounced regression of local cytokine imbalance and partial but significant restoration of sIgA level. The comprehensive treatment allowed compensation for some defects of mucosal immunity in CCLP, which was clinically accompanied by a decrease in respiratory morbidity.

The first stage of surgical treatment in children of group 1 was complicated by suppuration and/ or disruption of sutures, long courses of antibiotic therapy, a long period of stay in the hospital, and a long period of rehabilitation. However, the inclusion of local interferon therapy in the comprehensive treatment in patients of group 2 demonstrated a pronounced clinical effect, manifested in a decrease in the incidence of acute respiratory viral infections in $75.18 \pm 2.335$ cases, as well as the incidence of exacerbations of chronic foci of upper respiratory tract infection in $63.15 \pm 4.53 \%$ of cases, a decrease in the number of postoperative complications (suppuration of surgical sutures, surgical suture discrepancy) in all patients of this group $-100 \%$ of cases, faster healing of postoperative wounds in all patients, reduction of the duration of hospital stay by $25.34 \pm 0.98 \%$ as compared with group 1 , which patients were not received local interferon therapy $(\mathrm{p}<$ 0.05 ), a decrease in the duration of antibiotic use in $92.0 \pm 5.8 \%$ of children compared with group 1 $(\mathrm{p}<0.05)$, the effectiveness of rehabilitation increased in $100 \%$ of cases.

In addition, a 2.5-3-times decrease in the incidence of complicated and uncomplicated acute respiratory viral infections and their duration made it possible to conduct stage-by-stage surgical rehabilitation in time, to reduce in 1.3 times the number of hospital days and the duration of antibiotic therapy during surgical treatment, and also prevent the de-

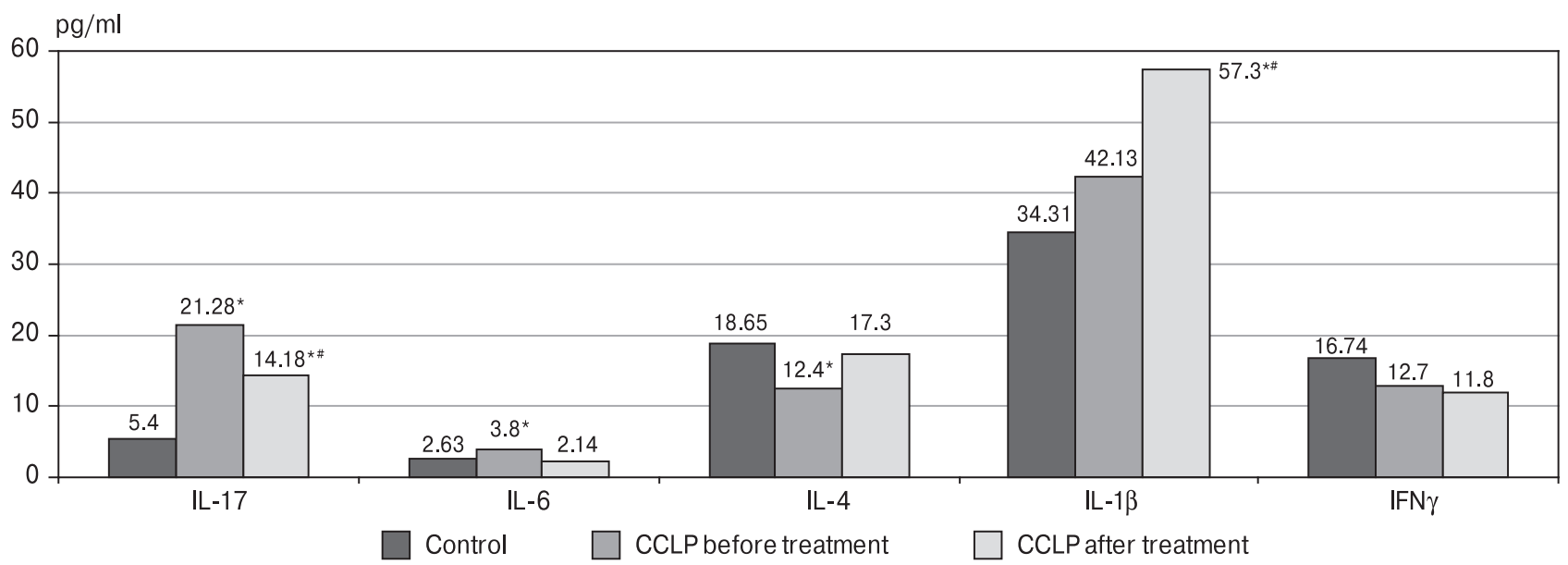

Figure 2. The cytokine profile of the oral fluid in children with congenital cleft lip and palate before and after local interferon therapy

Note: ${ }^{*} p<0,05$ compared with control group, ${ }^{*} p<0,05$ compared with group 2 before treatment. 
velopment of both early and long-term postoperative complications (tabl. 1).

Studies have shown that the implementation of complex treatment with the inclusion of local interferon therapy with recombinant interferon alfa- $2 b-$ Viferon-gel of children of the $2^{\text {nd }}$ group with CCLP allows to compensate for the disorders caused by both the functional immaturity of the immune system and the formation of various defects due to the presence of frequent respiratory infections due to congenital cleft lip and palate. Thus we noted the absence of various complications of the postoperative period, as well as a decrease in respiratory morbidity.

\section{Discussion}

Children of this age are characterized by a state of physiological inflammation of the gingival mucosa during teething, which in children with CCLP is associated with a constant additional viral load (persistence of respiratory and herpes viruses, acute herpetic stomatitis) and bacterial load represented by streptococcus associations At the same time there was a lack of acute clinical manifestations of the disease. Defects in the microbiocenosis of the mucous membranes of the oral and nasal cavity are the cause or consequence of the decrease in local and systemic immunity and of the immunity stress. Thus, a study of the ecological characteristics of the microflora of the oral cavity, nose and nasopharynx during cleft palate suggests that the pathology of the palate creates the conditions for the formation of dysbiosis in these biotopes, which is caused by certain physical, chemical and biological changes in the ecosystem, the degree of which increases with age.

It is notable, that an imbalance in the most important mediator of the inflammation development of IL-1 was revealed, the first manifestations of the biological effect of which are manifested in the activation of local protective reactions and anti-inflammatory IL- 4 together with IFN $\gamma$, which are key factors determining the type of immune response and potentiating the expression of the secretory component of IgA. The established defects of mucosal immunity necessitate the development of new approaches to local immunotropic therapy aimed at the restora- tion of mucosal immunity of the mucous membranes of the oral and nasal cavities, which contributes to the regression of established defects and prevents the occurrence of repeated respiratory infections and postoperative complications. The pathology of the interferon system of congenital or acquired origin is very diverse. Numerous studies of recent years have convincingly shown the existence of primary and secondary acquired disorders in the IFN system, which is clinically manifested by atypically occurring viral and viral-bacterial infections. At the same time, the development of unusual clinical symptoms follows changes in the IFN system that occur both at the cellular and molecular levels. The complex of immunorehabilitation measures for immunocompromised children with viral respiratory and herpetic infections uses recombinant IFN $\alpha 2 b$ in combination with antioxidants, due to the universal antiviral, antibacterial and immunomodulating nature of its action $[7,8]$.

\section{Conclusion}

Thus children with CCLP have clinical signs of secondary immunodeficiency with an infectious syndrome associated with impaired mucosal immunity, which is manifested in an imbalance of pro- and anti-inflammatory cytokines and a complete deficiency of secretory immunoglobulin A. Local interferon therapy, that is included in the comprehensive rehabilitation program, had a pronounced protective clinical effect, which was manifested in a decrease in the incidence of acute respiratory viral infections, a reduction of the number of postoperative complications, a reduction of the duration of hospital stay, a decrease in the duration of the use of antibacterial drugs, and a decrease in the number of exacerbations of chronic bacterial infection. Selected immunological criteria for assessing the state of mucosal immunity allow not only to conduct objective detection of its defects, but also to monitor the effectiveness of local interferon and immunotherapy.

\section{Acknowledgments}

This study was not supported by any organization or foundation.

\section{References}

1. Игнатьева О.В., Краснов М.В., Анохина А.В. Врожденные расщелины верхней губы и неба у детей в Чувашской Республике и оптимизация их лечения // Acta Medica Eurasica. 2015. № 3. С. 16-22. [Ignatyeva O., Krasnov M., Anokhina A. Congenital clefts of lip and palate in infants in chuvash republic and optimization of their treatment. Acta Medica Eurasica, 2015, no. 3, pp. 16-22. (In Russ.)]

2. Леонтьев В.К., Воронин В.Ф., Шестаков В.Т. Микрофлора полости рта. М.: Медицинская книга, 2000.21 с. [Leontyev V.K., Voronin V.F., Shestakov V.T. Microflora of the oral cavity. Moscow: Medical Book, 2000. 21 p. (In Russ.)]

3. Лобейко В.В., Иорданишвили А.К., Малышев М.Е. Возрастная характеристика иммунологических показателей слюны у взрослых людей // Кубанский научный медицинский вестник. 2015. T. 150, № 1. C. 74-79. [Lobeyko V.V., Iordanishvili A.K., Malyshev M.E. Markers of saliva secretory immunity of persons of different age, lives in St. Petersburg and Leningrad region. Kubanskiy nauchnyy meditsinskiy vestnik = Kuban Scientific Medical Bulletin, 2015, vol. 150, no. 1, pp. 74-79. doi: 10.25207/1608-6228-2015-1-74-79(In Russ.)] 
4. Митропанова М.Н. Особенности функционирования иммунной системы у детей с врожденными расщелинами губы и неба на этапах хирургического лечения // Стоматология детского возраста и профилактика. 2017. Т. 16, № 2 (61). C. 79-83. [Mitropanova M.N. Features of immunological system functioning in children with cleft lip and palate during surgical stage of treatment. Stomatologiya detskogo vozrasta i profilaktika = Pediatric Dentistry and Dental Prophylaxis, 2017, vol. 16, no. 2 (61), pp. 79-83. (In Russ.)]

5. Нестерова И.В. Препараты интерферона альфа в клинической практике: когда и как // Лечащий врач. 2017. Т. 9. C. 66-76. [Nesterova I.V. Interferon alpha drugs in clinical practice: when and how? Lechashchiy vrach = The Attending Physician, 2017, vol. 9, pp. 66-76. (In Russ.)]

6. Нестерова И.В., Ковалева С.В., Клещенко Е.И., Чудилова Г.А., Ломтатидзе Л.В., Шинкарева О.Н., Парфенов В.В., Кольцов В.Д. Оптимизация тактики интерфероно- и иммунотерапии в реабилитации иммунокомпрометированных детей с повторными респираторными и герпетическими вирусными инфекциями // Педиатрия. 2014. Т. 93 , № 3. C. 66-72. [Nesterova I.V., Kovaleva S.V., Kleshenko E.I., Chudilova G.A., Lomtatidze L.V., Shinkareva O.N., Parfenov V.V., Koltsov V.D. Optimization of interferon and immunotherapy tactics in the rehabilitation of immunocompromised children with repeated respiratory and herpetic viral infections. Pediatriya $=$ Russian Pediatrics, 2014, vol. 93, no. 3, pp. 66-72. (In Russ.)].

7. Нестерова И.В., Малиновская В.В., Тараканов В.А., Ковалева С.В. Интерфероно- и иммунотерапия в практике лечения часто и длительно болеющих детей и взрослых. США, Великобритания, Россия: Capricorn Publishing Inc., 2004. 160 c. [Nesterova I.V., Malinovskaya V.V., Tarakanov V.A., Kovaleva S.V. IFN and immune therapies in frequently and chronically ill children and adults treatment practice. USA, UK, Russia: Capricorn Publishing Inc., 2004. 158 p. (In Russ.)]

8. Симбирцев А.С., Лавренова Г.В. Иммунотерапия в практике ЛОР-врача и терапевта. СПб.: Диалог, 2018.456 с. [Simbirtsev A.S., Lavrenova G.V. Immunotherapy in the practice of ENT and the therapist. St. Petersburg: Dialogue, 2018. 456 p. (In Russ.)]

9. Black K.P., Merril K.W., Jackson S., Kats J. Cytokine profiles in parotid saliva from HIV-1-infected individuals: changes associated with opportunistic infections in the oral cavity. Oral Microbiology and Immunology, 2000, vol. 15, no. 2, pp. 74-81. doi: 10.1034/j.1399-302x.2000.150202.x

10. Gao L., Xu T., Huang G., Jiang S., Gu Y., Chen F. Oral microbiomes: more and more importance in oral cavity and whole body. Protein \& Cell, 2018, vol. 9, no. 5, pp. 488-500. doi: 10.1007/s13238-018-0548-1

11. Kagami H., Hiramatsu Y., Hishida S., Okazaki Y., Horie K., Oda Y., Ueda M. Salivary growth factors in health and disease. $A d v$. Dent. Res., 2000, vol. 14, no. 1, pp. 99-102. doi: 10.1177/08959374000140011601

\section{Авторы:}

Нестерова И.В., д.м.н., профессор, профессор кафедры аллергологии и иммунологии Факультета непрерывного медицинского образования ФГАБОУ ВО Российский университет дружбы народов Министерства образования и науки России, Москва, Россия; главный научный сотрудник отдела клинической и экспериментальной иммунологии и молекулярной биологии центральной научноисследовательской лаборатории ФГБОУ ВО Кубанский государственный медицинский университет Минздрава России, г. Краснодар, Россия;

Митропанова М.Н., к.м.Н., доцент, зав. кафедрой детской стоматологии, ортодонтии и челюстно-лицевой хирургии Факультета непрерывного медицинского образования ФГАБОУ ВО Российский университет дружбы народов Министерства образования и науки России, Москва, Россия;

Чудилова Г.А., к.б.Н., доцент, зав. отелом клинической и экспериментальной иммунологии и молекулярной биологии центральной научно-исследовательской лаборатории Факультета непрерывного медицинского образования ФГАБОУ ВО Российский университет дружбы народов Министерства образования и науки России, Москва, Россия;

Ковалева С.В., К.м.н., доцент, старший научный сотрудник отдела клинической и экспериментальной иммунологии и молекулярной биологии центральной научноисследовательской лаборатории Факультета непрерывного медицинского образования ФГАБОУ ВО Российский университет дружбы народов Министерства образования и науки России, Москва, Россия;

Халтурина Е.О., к.м.н., доцент кафедры микробиологии, вирусологии и иммунологии Первого Московского государственного медицинского университета им. И.М. Сеченова (Сеченовский университет), Москва, Россия.

Поступила в редакцию 06.01.2020

Принята к печати 14.03.2020

\section{Authors:}

Nesterova I.V., PhD, MD (Medicine), Professor, Professor of the Department of Allergology and Immunology, Faculty of Continuing Medical Education, RUDN University, Moscow, Russian Federation; Head Researcher, Department of Clinical and Experimental Immunology and Molecular Biology, Central Scientific Research Laboratory, Kuban State Medical University, Krasnodar, Russian Federation;

Mitropanova M.N., PhD (Medicine), Associate Professor, Head of the Department of Pediatric Dentistry, Orthodontics and Dentofacial Surgery, Faculty of Continuing Medical Education, RUDN University, Moscow, Russian Federation;

Chudilova G.A., PhD (Biology), Associate Professor, Head of the Department of Clinical and Experimental Immunology and Molecular Biology, Central Scientific Research Laboratory, Faculty of Continuing Medical Education, RUDN University, Moscow, Russian Federation;

Kovaleva S.V., PhD (Medicine), Assistant Professor, Senior Researcher, Department of Clinical and Experimental Immunology and Molecular Biology, Central Scientific Research Laboratory, Faculty of Continuing Medical Education, RUDN University, Moscow, Russian Federation;

Khalturina E.O., PhD (Medicine), Associate Professor, Department of Microbiology, Virology and Immunology, I.M. Sechenov First Moscow State Medical University (Sechenov University), Moscow, Russian Federation. 